\title{
Molecular fingerprinting of methicillin resistant Staphylococcus aureus strains isolated from human and poultry in Duhok, Iraq
}

\author{
H.A. Hado ${ }^{1}\left[\right.$ and M.S. Assafi ${ }^{\circledR}$ \\ ${ }^{1}$ Department of Biology, Faculty of Sciences, University of Zakho, Zakho, ${ }^{2}$ Department of Biology, School of Sciences, \\ University of Duhok, Duhok, Iraq
}

\begin{tabular}{l} 
Article information \\
\hline Article history: \\
Received December 07, 2019 \\
Accepted January 20, 2020 \\
Available online November 1, 2020 \\
\hline Keywords: \\
MRSA \\
RAPD-PCR \\
Chicken \\
Farm workers \\
Duhok \\
\hline
\end{tabular}

Correspondence:

M.S. Assafi

mahde.assafi@uod.ac

\begin{abstract}
Methicillin-resistant Staphylococcus aureus (MRSA) has been recently identified in poultry and farm workers. The aim of this work was to investigate the epidemiological relatedness of MRSA among chickens and farmworker. MRSA isolates $(n=50)$ from human $(n=14)$ and from chikens $(n=36)$ were tested for molecular epidemiological relatedness between human and poultry. RAPD-PCR was carried out for fingerprinting of MRSA isolates genome. Seven genotypes group (A-G) have been identified. All human MRSA were belonging to genotype A. Whereas, chickens MRSA isolates was belonging to different genotype patterns groups (A-G). To conclude, human MRSA was belonging to one genotype pattern but the chickens MRSA strains were belonging to seven genotypes. The genotype pattern A was the most dominant among all MRSA isolates. It is possible that the chickens play an important role for the human exposure to MRSA by direct contact. Further studies are required to address the relatedness between human and chicken MRSA.
\end{abstract}

DOI: 10.33899/ijvs.2020.126375.1310, (C2021, College of Veterinary Medicine, University of Mosul.

This is an open access article under the CC BY 4.0 license (http://creativecommons.org/licenses/by/4.0/).

\section{Introduction}

Staphylococcus aureus (S. aureus) is an opportunistic pathogen capable of causing different infections in humans and animals (1). In 1961, there were reports on $S$. aureus isolates that had acquired resistance to methicillin and this was so-called methicillin-resistant $S$. aureus (MRSA) (2). MRSA which is a specific strain of the $S$. aureus that has acquired and developed resistance to all beta-lactamase antibiotics including, methicillin, penicillin, and other narrow-spectrum antibiotics (3). Depending on the clinical isolates, up to $50 \%$ of $S$. aureus infections are caused by MRSA. Nowadays, MRSA is subdivided into three main categories, hospital-associated MRSA (HAMRSA), livestock-associated MRSA (LA-MRSA) and Community-associated MRSA (CA-MRSA) (4,5). Many studies have documented that different MRSA nasal carriage rates have been observed in the Iraqi people (6-8). Chicken infectious diseases are a main economic burden on the poultry industry, $S$. aureus infection in commercial broiler chickens can cause septic arthritis, septicemia, subdermal abscesses (bumble-foot), omphalitis and gangrenous dermatitis (9,10). Animals can become reservoirs for MRSA and spread it to other animals and even human (11). Human in close contact with animals are at high risk for MRSA colonization $(12,13)$. The poultry meat has been implicated as a main source of MRSA in humans $(14,15)$. In a study, a lineage of MRSA in retail chicken meat was observed and suggested to be of human origin (16). Recently, a high prevalence MRSA isolates were observed in both farm workers and chickens in Duhok, Iraq (17). The present study aimed to investigate the epidemiological relatedness of MRSA strains among chickens and farmworker in Duhok, Iraq.

\section{Material and methods}

\section{Methicillin resistant $S$. aureus isolates}

Staphylococcus aureus and MRSA isolates from adult farm workers (Workers with history of hospitalization, 
surgery, dialysis or residence in a long-term care facility, and history of previous isolation of MRSA were excluded) and chickens (Commercial broiler collected from different farms in all districts in Duhok city) were previously isolated and identified using conventional bacteriological, biochemical and molecular methods (17). 50 MRSA isolates (14 from Human and 36 from chikens) were selected and screened for the molecular typing.

\section{RAPD-PCR typing of methicillin resistant $S$. aureus}

Randomly amplified polymorphic DNA (RAPD)-PCR technique was applied for the identifying genomic variation and establishing strain-specific fingerprints of the isolated MRSA strains. Short synthetic oligonucleotide primer (Eric2: 5'AAGTAAGTGACTGGGGTGAGCG3') with a random sequence about 22 bases in length was used for this purpose $(18,19)$.

\section{Genomic DNA extraction}

DNA was extracted from $S$. aureus isolates using DNA isolation kit according to the company's guidelines (AccuVi Bio, UAE). In brief, $1 \mathrm{ml}$ of an overnight broth culture was centrifuged at $14,000 \mathrm{rpm}$ for $30 \mathrm{~s}$ and $250 \mu \mathrm{l}$ of suspension solution was added to the cell pellet. Next, 250 $\mu \mathrm{l}$ of lysis solution and $12 \mu \mathrm{l}$ of proteinase $\mathrm{k}$ were added and incubated at $55 \mathrm{oC}$ for $30 \mathrm{~min}$. $500 \mu \mathrm{l}$ of binding solution was added and centrifuged at $8,000 \mathrm{rpm}$ for $1 \mathrm{~min}$. The flow through was discarded and the mixture was washed twice by $500 \mu \mathrm{l}$ of wash solution. Then, the DNA was eluted in $200 \mu$ l elution buffer at $6,000 \mathrm{rpm}$ for $1 \mathrm{~min}$. The purity and concentration of DNA of each isolate was measured by using Nanodrop device (Thermo scientific, USA).

\section{Polymerase chain reaction (PCR)}

PCR reactions were carried out in a C1000 thermal cycler (Bio-Rad, USA). PCR amplification reactions were achieved in a final volume of $20 \mu \mathrm{l}$. The components, volumes, and concentrations used were: $10 \mu \mathrm{l}$ of deoxyribonucleotide master mix (Promega, USA); $2 \mu \mathrm{l} S$. aureus genomic DNA (final concentration 50-100 ng/ml), 1 $\mu 1$ for primer (Eric2) in a final concentration $10 \mathrm{pmol} / \mu 1$, and nuclease-free water to a final volume of $20 \mu \mathrm{l}$. The PCR conditions were: $1 \mathrm{~min}$ for initial template denaturation step at $95{ }^{\circ} \mathrm{C}$, followed by 30 cycles of denaturation at $94^{\circ} \mathrm{C}$ for $45 \mathrm{~s}$; annealing for $27^{\circ} \mathrm{C}$ for $1 \mathrm{~min}$, and extension at $72^{\circ} \mathrm{C}$ for $2 \mathrm{~min}$. These cycles were followed by a final extension step $72^{\circ} \mathrm{C}$ for 5 min followed by hold step at $4^{\circ} \mathrm{C}$.

\section{Gel electrophoresis}

DNA bands of the amplified PCR products were separated on agarose gel according to their sizes. The electrical power was turn on $65 \mathrm{~V}$. for $50 \mathrm{~min} 1 \mathrm{x}$ TBE buffer. Ethidium bromide at a final concentration of $5 \mu \mathrm{g}$ $\mathrm{ml}^{-1}$ was used to stain the agarose gels. The separated fragments were visualized using a U.V. illumination at 366 nm wavelengths (HVD life science, Austria).

\section{Results}

At the present study, the genomic variation among human MRSA and chicken MRSA was evaluated utilizing Eric2 primer in randomly amplified polymorphic DNA (RAPD)-PCR technique. Among the 50 MRSA tested, seven different random amplification polymorphic DNA patterns (genotypes) have been identified and termed A, B, C, D, E, F, and G (Fig 1). Random amplified polymorphic DNA (RAPD) method was generated for MRSA strains to detect genetic relationship in an epidemiological sense. It implicates the amplification of arbitrarily selected chromosomal DNA sequences with a short primer with a random sequence not useful to a specific region of the DNA target, but capable of hybridization at random chromosomal sites, the amount and locations of these arbitrary sites will differ among various strains, producing a different RAPDPCR profile based on the number and sizes of the fragments detected by electrophoresis.

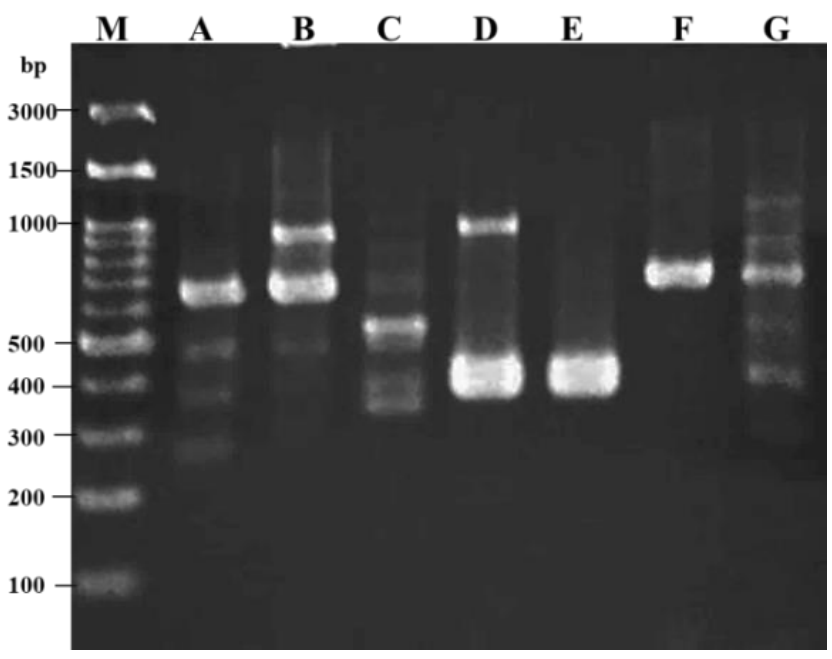

Figure 1: RAPD-PCR profiles and the banding pattern of MRSA selected from two sources and generated with primer Eric2 with a different molecular weight about (2001000bp). Lane M is DNA ladder, lane A represent MRSA isolates from workers and chickens samples, lanes B-G MRSA isolates represent chickens samples.

All tested human MRSA ( $\mathrm{n}=14)$ were belonging to genotype group A, whereas 10 out 36 chicken MRSA were belonging to group $\mathrm{A}$. While the remaining 26 chicken MRSA typing isolates were from B, C, E, F and, G groups while all human isolates detected negative for these groups (Table 1). 
Table 1: Genotype patterns generated by RAPD PCR for MRSA isolates

\begin{tabular}{lccc}
\hline \multirow{2}{*}{ Genotype } & \multicolumn{2}{c}{ MRSA } & \multirow{2}{*}{ No. of bands } \\
\cline { 2 - 3 } & Chicken & Human & \\
\hline A & 10 & 14 & 4 \\
B & 5 & 0 & 3 \\
C & 6 & 0 & 5 \\
D & 4 & 0 & 2 \\
E & 5 & 0 & 1 \\
F & 4 & 0 & 2 \\
G & 2 & 0 & 5 \\
\hline
\end{tabular}

\section{Discussion}

Staphylococci can cause different patterns of infections in human such as, bone infection, heart infection and serious skin infections $(20,21)$. S. aureus enterotoxins can cause food poisoning, toxic shock syndrome and urinary tract infections $(22,23)$. MRSA is a common bacterial pathogen responsible for a variety of infections and widely distributed among societies $(24,25)$. Poultry $S$. aureus can become a zoonotic risk factors and cause food poisoning in human especially in case of insufficient cooking of chickens portions (26). Recently MRSA have been found in farms animals particularly in chickens, the incidence of MRSA in Duhok, Iraq was 27.3\% (17). In Jordan, MRSA was detected in $4 \%$ in poultry (27). While in UK broiler farms was about $(74 \%)$, in Germany about $21 \%$, and high levels of poultry MRSA have also been found in Denmark, Austria and Norway and (28).

At the present study, seven different RAPD patterns (genotypes) were identified. All human MRSA were belonging to one genotype (group A) and 27/8\% (10/36) of chicken MRSA was belonging to this group. While the remaining chicken MRSA were identified as B, C, E, F and, $\mathrm{G}$ groups. This may show the close relationship between isolates, and may have deviated from same precursor or comes from human and vice versa through handling of contaminated chickens with bacterium or other transmission facility at different stages of farming. This could indicate that there was no transmission of MRSA among human and chicken and may be due to hygiene precautions of workers (15).

MRSA have been found in farms animals particularly in chickens (27). Animals can become reservoirs for MRSA and spread it to other animals and even human (29). MRSA infection and colonization has been noticed in human after a time of directly and close contact with infected animals (30). A number of LA-MRSA strains such as CC398, are shown to be transmitted between species, particularly after inhalation of contaminated dust, which could contain a large numbers of bacteria and these suggested to be a major way of the dissemination of these organisms in close hall system (31).
People commonly become colonized with LA-MRSA strains, after physical contact with live birds and farms environments or consumption of improper cocked meats $(32,33)$, and also can be transmitted between people and family members, particularly who live together within household (34). Animals usually acquire the organisms from the mothers and can also horizontally acquire these organisms during growing life from other animals or from the environment. However evidence from parent MRSA colonization shows a little influence on their offspring after a time, because MRSA can change their rates more than once from birth to full growth, this, has proved by prevalence of $S$. aureus between different sampling points (35).

The transmission of MRSA between chickens in farms are most commonly occur due to contamination of farms inhabitance and the organisms may shed into the feeds and water vessel from the nostrils, or through their fecal materials, the organisms shed on the surface ground of household, as well as through vaccinations and treatment of chickens with contaminated injections (35).

Colonization is one of the major risk factors for $S$. aureus infections. In humans $S$. aureus have wildly colonized the anterior nares but has also been isolated from healthy skin, axilla, perineum throat, trachea of ventilated patients, cervical swabs and from the urethra of previously catheterized patients (36-38).

Many researchers suggested that MRSA isolates are able to move between humans and animals, however the successful transfer of these bacteria between humans and poultry is not very clear, but the data from a study showed that infection of humans by transmission through direct contact and food products polluted with poultry MRSA is very possible. Lee (15) revealed that six animals isolates were identical to the patterns of certain humans isolates, also, it was reported that a cat's isolate was indistinguishable from the Pulsed-field gel electrophoresis (PFGE) pattern of the human epidemic strain (39). It is possible that the MRSA isolates could transmit from human to chicken and vice versa. Therefore, these isolates can become widespread in the community atmosphere of Duhok province, Iraq, where antibiotics such as vancomycin, and amikacin are not used for animal treatment, these can raise the occurrence of MRSA strains among humans.

\section{Conclusions}

All farm workers MRSA isolates showed identical patterns of RAPD-PCR with chicken MRSA isolates. However, not all chicken MRSA isolates were identical to human MRSA. It is possible that the MRSA isolates could transmit from human to chicken and vice versa. Further investigations are required to study the relatedness between human and chicken MRSA using different typing approaches. 


\section{Acknowledgements}

We would like to thank veterinary department, Dohuk governorate for providing the approval to access the farms. Also, we thank all participants and farm owners for their collaboration during sample collection.

\section{Conflict of Interest}

The authors declare that there is no conflict of interest.

\section{References}

1. Wertheim HF, Melles DC, Vos MC, van Leeuwen W, van Belkum A, Verbrugh HA, Nouwen JL. The role of nasal carriage in Staphylococcus aureus infections. Lancet Infect Dis. 2005;5(12):751762. Doi: $10.1016 /$ S1473-3099(05)70295-4

2. Enright MC, Robinson DA, Randle G, Feil EJ, Grundmann H, Spratt BG. The evolutionary history of methicillin-resistant Staphylococcus aureus (MRSA). PNAS. 2002; 99(11):7687-7692. Doi: 10.1073/pnas.122108599

3. Foster. Staphylococcus. In: Barron S. Barron's medical microbiology. $4^{\text {th }}$ ed. Texas: University of Texas Medical Branch; 1996. 31-116.

4. Wendlandt S, Fessler AT, Kadlec K, van Duijkeren E, Schwarz S. Identification of the novel spectinomycin resistance gene spd in a different plasmid background among methicillin-resistant Staphylococcus aureus CC398 and methicillin-susceptible S. aureus ST433. J Antimicrob Chemother. 2014;69(7):2000-2003. Doi: $\underline{10.1093 / \mathrm{jac} / \mathrm{dku} 067}$

5. David MZ, Daum RS. Community-associated methicillin-resistant Staphylococcus aureus: Epidemiology and clinical consequences of an emerging epidemic. Clin Microbiol Rev. 2013;23(3):616-687. Doi: 10.1128/CMR.00081-09

6. Habeeb A, Hussein NR, Assafi MS, Al-Dabbagh SA. Methicillin resistant Staphylococcus aureus nasal colonization among secondary school students at Duhok City-Iraq. J Microbiol Infect Dis. 2014;4(2):59-63. Doi: 10.5799/ahinjs.02.2014.02.0128

7. Hussein NR, Assafi MS, Ijaz T. Methicillin-resistant Staphylococcus aureus nasal colonization amongst healthcare workers in Iraq. J Glob Antimicrob Resist. 2017;9:78-81. Doi: 10.1016/j.jgar.2017.01.010

8. Ibrahim HT, Al-Mathkhury HJF. pvl-carried methicillin resistant Staphylococcus aureus isolated from hospitalized patients in Baghdad, Iraq. Iraqi $\mathrm{J}$ of Science. 2018;59(4B):1967-1972. Doi: 10.24996/ijs.2018.59.4B.1

9. Smyth JA, McNamee PT. Staphylococci, Streptococci and Enterococci. In: Jordan F, Pattison M, Alexander D, Faragher T. Poultry diseases. $6^{\text {th }}$ ed. London: Elsevier Health Sciences; 2001. 191$199 \mathrm{p}$.

10. Sadeq JN, Fahed Kh H, Hassan HJ. Detection of Escherichia coli hlyA gene and Staphylococcus aureus Sea gene in raw milk of buffaloes using RT-PCR technique in AL- Qadisiyah province. Iraqi J Vet Sci. 2018;32(1):87-91. Doi: 10.33899/ijvs.2018.153815

11. Rosen K, Roesler U, Merle R, Friese A. Persistent and transient airborne MRSA colonization of piglets in a newly established animal model. Front Microbiol. 2018;9:1542. Doi: 10.3389/fmicb.2018.01542

12. Fessler AT, Schuenemann R, Kadlec K, Hensel V, Brombach J, Murugaiyan J, Oechtering G, Burgener IA, Schwarz S. Methicillinresistant Staphylococcus aureus (MRSA) and methicillin-resistant Staphylococcus pseudintermedius (MRSP) among employees and in the environment of a small animal hospital. Vet Microbiol. 2018;221:153-158. Doi: 10.1016/j.vetmic.2018.06.001

13. Asanin J, Misic D, Aksentijevic K, Tambur Z, Rakonjac B, Kovacevic I, Spergser J, Loncaric I. Genetic profiling and comparison of human and animal methicillin-resistant Staphylococcus aureus (MRSA) isolates from Serbia. Antibiotics. 2019;8(1):26. Doi: 10.3390/antibiotics8010026

14. Malheiros PS, Passos CT, Casarin LS, Serraglio L, Tondo EC. Evaluation of growth and transfer of Staphylococcus aureus from poultry meat to surfaces of stainless steel and polyethylene and their disinfection. Food Control. 2010;21:298-301. Doi: 10.1016/j.foodcont.2009.06.008

15. Lee JH. Methicillin (Oxacillin)-resistant Staphylococcus aureus strains isolated from major food animals and their potential transmission to humans. Appl Environ Microbiol. 2003;69(11):64896494. Doi: $10.1128 /$ aem.69.11.6489-6494.2003

16. Bernier-Lachance J, Arsenault J, Usongo V, Parent E, Labrie J, Jacques M, Malouin F, Archambault M. Prevalence and characteristics of livestock-associated methicillin-resistant Staphylococcus aureus (LA-MRSA) isolated from chicken meat in the province of Quebec, Canada. PLoS One. 2020;15(1):e0227183. Doi: 10.1371/journal.pone. 0227183

17. Assafi MS, Hado HA, Abdulrahman IS. Detection of methicillinresistant Staphylococcus aureus in broiler and broilers farm workers in Duhok, Iraq by using conventional and PCR techniques. Iraqi J Vet Sci. 2020;34(1):15-22. Doi: 10.33899/ijvs.2019.125757.1145

18. van Belkum, Bax AR, Peerbooms P, Goessens WH, van Leeuwen N, Quint WG. Comparison of phage typing and DNA fingerprinting by polymerase chain reaction for discrimination of methicillin-resistant Staphylococcus aureus strains. J Clin Microbiol. 1993;31(4):798-803. Doi: 10.1128/JCM.31.4.798-803.1993

19. Palavecino E. Community-acquired methicillin-resistant Staphylococcus aureus infections. Clin Lab Med. 2004;24(2):403-Doi: 418. 10.1016/j.cll.2004.03.007

20. Tong SYC, Davis JS, Eichenberger E, Holland TL, Fowler VG. Staphylococcus aureus Infections: Epidemiology, Pathophysiology, Clinical Manifestations, and Management. Clin Microbiol Rev. 2015; 28(3): 603-661. Doi: 10.1128/CMR.00134-14

21. Foster TJ. Potential for vaccination against infections caused by Staphylococcus aureus. Vaccine. 1991;9(4):221-227. Doi: 10.1016/0264-410X(91)90103-D

22. Prevost G, Couppie P, Prevost P, Gayet S, Petiau P, Cribier B, Monteil H, Piemont Y. Epidemiological data on Staphylococcus aureus strains producing synergohymenotropic toxins. J Med Microbiol. 1995;42(4):237-245. Doi: 10.1099/00222615-42-4-237

23. Rupp ME, Archer GL. Coagulase-negative Staphylococci: Pathogens associated with medical progress. Clin Infect Dis. 1994;19(2):231243. Doi: $10.1093 /$ clinids/19.2.231

24. Assafi MS, Polse RF, Hussein NR, Haji AH, Issa AR. The Prevalence of $S$. aureus nasal colonisation and its antibiotic sensitivity pattern amongst primary school pupils. Sci J Uni Zakho. 2017;5(1):7-10. Doi: 10.25271/2017.5.1.291

25. Al. Zebary MK, Yousif SY, Assafi MS. The prevalence, molecular characterization and antimicrobial susceptibility of $S$. aureus isolated from impetigo cases in Duhok, Iraq. The Open Dermatology Journal. 2017;11: 22-29. Doi: 10.2174/1874372201711010022

26. Santivatr D, Maheswaran SK, Newman JA, Pomeroy BS. Effect of infectious bursal disease virus infection on the phagocytosis of Staphylococcus aureus by mononuclear phagocytic cells of susceptible and resistant strains of chickens. Avian Dis. 1981;25(2):303-311. Doi: $10.2307 / 1589924$

27. Quddoumi SS, Bdour SM, Mahasneh AM. Isolation and characterization of methicillin-resistant Staphylococcus aureus from livestock and poultry meat. Ann Microbiol. 2006;56(2):155-161. Doi: 10.1007/BF03174998

28. Heuer OE, Pedersen K, Andersen JS, Madsen M. Vancomycinresistant enterococci (VRE) in broiler flocks 5 years after the avoparcin ban. Microb Drug Resist. 2002;8(2):133-138. Doi: $10.1089 / 107662902760190680$

29. Agerso Y, Vigre H, Cavaco LM, Josefsen MH. Comparison of air samples, nasal swabs, ear-skin swabs and environmental dust samples for detection of methicillin-resistant Staphylococcus aureus (MRSA) in pig herds. Epidemiol Infect. 2014;142(8):1727-1736. Doi: 10.1017/S095026881300280X 
30. Becker K, Ballhausen B, Kahl BC, Kock R. The clinical impact of livestock-associated methicillin-resistant Staphylococcus aureus of the clonal complex 398 for humans. Vet Microbiol. 2017;200:33-38. Doi: 10.1016/j.vetmic.2015.11.013

31. Bergonier D, Sobral D, Fessler AT, Jacquet E, Gilbert FB, Schwarz S, Treilles M, Bouloc P, Pourcel C, Vergnaud G. Staphylococcus aureus from 152 cases of bovine, ovine and caprine mastitis investigated by Multiple-locus variable number of tandem repeat analysis (MLVA). Vet Res. 2014;45:97. Doi: 10.1186/s13567-014-0097-4

32. Oke AJ, Oke A. Incidence of methicillin-resistant Staphylococcus aureus (MRSA) in a small poultry in south-west, Nigeria. IOSR J Agri Vet Sci. 2013;5:53-55. Doi: 10.9790/2380-0535355

33. Garcia-Graells C, van Cleef BA, Larsen J, Denis O, Skov R, Voss A. Dynamic of livestock-associated methicillin-resistant Staphylococcus aureus CC398 in pig farm households: a pilot study. PLoS One. 2013;8(5):e65512. Doi: 10.1371/journal.pone.0065512

34. Graveland H, Wagenaar JA, Bergs K, Heesterbeek H, Heederik D. Persistence of livestock associated MRSA CC398 in humans is dependent on intensity of animal contact. PLoS One. 2011;6(2):e16830. Doi: 10.1371/journal.pone.0016830

35. Burns A, Shore AC, Brennan GI, Coleman DC, Egan J, Fanning S, Galligan MC, Gibbons JF, Gutierrez M, Malhotra-Kumar S, Markey BK, Sabirova JS, Wang J, Leonard FC. A longitudinal study of Staphylococcus aureus colonization in pigs in Ireland. Vet Microbiol. 2014;174(3-4):504-513. Doi: 10.1016/j.vetmic.2014.10.009

36. Vannuffel P, Laterre PF, Bouyer M, Gigi J, Vandercam B, Reynaert M, Gala JL. Rapid and specific molecular identification of methicillinresistant Staphylococcus aureus in endotracheal aspirates from mechanically ventilated patients. J Clin Microbiol. 1998;36(8):23662368. Doi: 10.1128/JCM.36.8.2366-2368.1998

37. Smith CB, Noble V, Bensch R, Ahlin PA, Jacobson JA, Latham RH. Bacterial flora of the vagina during the menstrual cycle: findings in users of tampons, napkins, and sea sponges. Ann Intern Med. 1982;96(6 Pt 2):948-951. Doi: 10.7326/0003-4819-96-6-948

38. Assafi MS, Mohammed RQ, Hussein NR. (2015). Nasal Carriage Rates of Staphylococcus aureus and CA-Methicillin Resistant Staphylococcus aureus among University Students, J of Microbiol. Res. 2015;5(4).123-127. Doi: 10.5923/j.microbiology.20150504.01

39. Walther B, Wieler LH, Friedrich AW, Hanssen AM, Kohn B, Brunnberg L, Lubke-Becker A. Methicillin-resistant Staphylococcus aureus (MRSA) isolated from small and exotic animals at a university hospital during routine microbiological examinations. Vet Microbiol. 2008;127(1-2):171-178. Doi: 10.1016/j.vetmic.2007.07.018

\section{التنميط الوراثي الجزيئي للمكورات العنقودية الذهبية المقاومة للمثيسيلين المعزولة من المئينة الدواجن وعمال حقول الدواجن في مدينة دهولك، العراق من الدئ هوشيار عبدالجبار حدو' و مهدي صالح العسافي} جامعة دهوك، دأحياء، كلية العلوم، جامعة زاخو، العراق زاخو، ‘ قسم الأحياء، كلية العلوم،

الخلاصة

جراثيم المكورات العنقودية المقاومة للمثيسيلين شخصت هديث الثيثا في

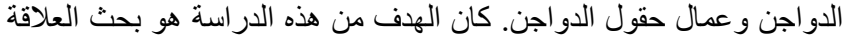



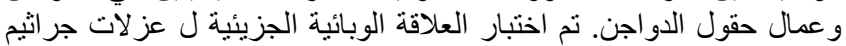

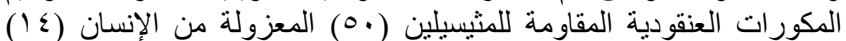

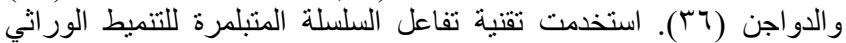

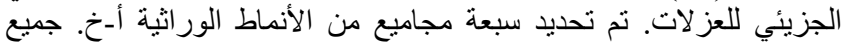

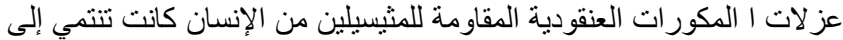

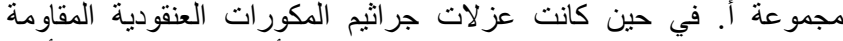

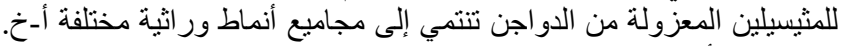

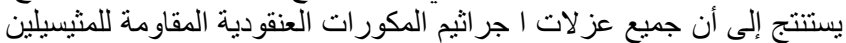

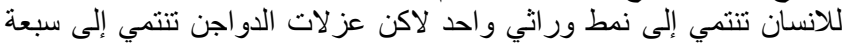

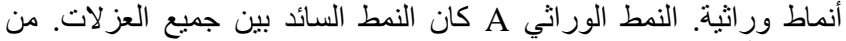

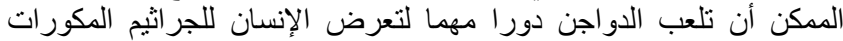

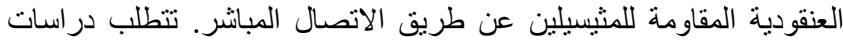

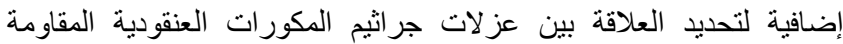
للمثيسيلين في الإنسان و الدواجن. 